\title{
RISKS AND TRANSFER PRICING REGULATION \\ AT THE MULTINATIONAL ENTERPRISES' ROUTINE UNITS: \\ A LITERATURE REVIEW
}

\section{Tomáš Buus*}

\begin{abstract}
Multinational enterprises (MNE) allocate valuable intangible assets and strategic functions to the strategy units (usually parent companies) for that allows them to impropriate the majority of the profits there and protect those assets from subsidiaries' risks. The subsidiaries are frequently routine units. Subsequently, the routine units receive low reward, as they perform only routine functions. The OECD transfer pricing guidelines support that practice to the detriment of government budgets and public by considering the routine units as the low-risk ones. This paper reviews the relevant literature and shows that the traditional view of risk and profit allocation between strategy and routine units is inconsistent with their relative risks, resp. with relative risks of MNE's subsidiary and independent company. The long-term perspective of MNEs' members' downside risks provides correct information for transfer pricing regulation and fiscal authorities. Results of this paper enable proposal of the transfer pricing risk analysis targets and tools.
\end{abstract}

Keywords: multinational corporation, multinational enterprise, routine unit, stakeholder, risk, profit shifting

JEL Classification: H25, H26, H87

\section{Introduction}

Tucha and Brem (2007, p. 154) describe the profitability of companies, which perform routine functions in MNEs, by the following words: "In the absence of economic turbulence, companies with routine functions achieve small but constant profit margins. For transfer pricing analysis purposes, such routine functions (or routine business units) are assigned with gross or net markups as reflected in the Cost Plus Method or Resale Minus Method." The above citation quite comprehensively describes the standpoint of official guidelines (OECD, 2010), and the practice.

The transfer pricing guidelines are legally binding for the national tax authorities, wherever the double taxation treaties would apply in OECD countries under article 9 of the model tax convention. However, the recommended and heavily used transfer pricing statistics - interquartile range (Eden 2012, or chapter $26 \S 1.482-1$ of the Code of Federal Regulations in the case of USA) - create an opportunity to shift the majority of the profit through the choice of the transfer price within the acceptable range.

* Tomáš Buus, Department of Corporate Finance, Faculty of Finance and Accounting, University of Economics, Prague, Czech Republic (buust@vse.cz).

This paper is one of the outcomes of the University of Economics in Prague, Faculty of Finance and Accounting Research Project and has been financed by the institutional support VSE IP100040. 
Multinational enterprises (hereinafter MNE) exploit that opportunity unscrupulously (cp. Rahman and Scapens, 1986). MNEs shift profits to low-tax jurisdictions via location of the elusive and flexible intangible assets (Dischinger and Riedel, 2011; Beer and Loeprick, 2015), and via other techniques like debt location in high-tax jurisdictions or hybrid capital instruments (Gravelle, 2010), while both of these instruments being probably substitutes (Saunders-Scott 2016). Nevertheless, the transfer pricing decisions are frequently not linked to real investments, contrary to the unfortunate assumptions used by the majority of theoretic research in this area. Maffini and Mokkas (2011) provide evidence of separability, and separation, of profit shifting stemming from other corporate decisions.

The increasingly unsustainable share of public debt on GDP, and the impact of financial crisis on the socially weak people both highlight the need for a systematic inquiry into riskreturn relationship in the controlled transactions. Moreover, the profit shifting techniques, which are mostly conducted via transfer pricing, leave many of the corporate-risk bearers vulnerable. Sikka and Willmott (2010) provide evidence that "Transfer pricing practices are responsive to opportunities for determining values in ways that are consequential for enhancing private gains, and thereby contributing to relative social impoverishment, by avoiding the payment of public taxes."

To answer the above challenges, this paper surveys previous empirical literature regarding the appropriate risk measures, the distribution of subsidiaries' risks, and exit hazard of MNE routine and strategy units.

The main contributions and findings of this paper are:

1) The contemporary transfer pricing practice contradicts the nature and scope of risks borne by the strategy and routine units.

2) The present regulation does not properly consider the interests of stakeholders, except for shareholders.

3) Routine units and MNE subsidiaries can be considered generally low-risk only in the short term.

\section{The Allocation of Upside and Downside Risks among Stakeholders}

Tucha and Brem (2007, p. 154) note that MNEs hedge the routine unit risks by means of contracts with suppliers or customers. Assigning low risk assessment, thereby also low margins, to the company, which transfers risks on its suppliers, employees and society, is misinterpretation of Friedman's (1962) shareholder theory, which leads to unfair transfer pricing. Low margins leave the society with low reimbursement for such risk taking.

Transfer price also influences the level of cash held by the related party. Therefore, it also influences the satisfaction of legal claims of all stakeholders. Shareholders' claims are by law subordinated to the claims of the following stakeholders: government (entitled to levy taxes), employees (who have right to receive wages for their work), suppliers, and creditors, in the case of such a prioritization need. However, MNE can reverse that order by transfer pricing. 
Governments levy taxes on all constituents of value added through taxation of wages, profits, and value added itself. The focus of tax legislation shifts from direct taxes to indirect ones, at least in the EU27 (Dugová, 2013). Tax is, at least partially, beyond any doubt a price for public services (Hettich, 2005, p. 420). Indeed, the relationship between GDP tax quota and public services is evident and closely relates to the protection of property rights, which allows the capital holders to earn money in exchange for paying some taxes (Timmons, 2005). Therefore, the public infrastructure and government institutions embody an asset, from which the taxpayers (including MNEs's subsidiaries) benefit.

Human capital is risky investment, since it is inseparably fixed to its owner (Schultz, 1972, p. 8). Capitalist nature of contemporary markets endangers the entitlement of workers to receive a rent in exchange for exploitation of their skills (Bowles and Gintis, 1975; Grosfeld and Nivet, 1999). Employees earn wages for their work and learn some skills, while working at MNEs' subsidiaries. However, those skills are frequently highly specialized. Employer benefits from such highly specialized skills more than the employee, if those skills are company-specific. Employees with universal, high productivity skills, who voluntarily exit the multinational subsidiary, usually experience wage increase on the domestic labour market (Sofka, Preto and de Faria, 2014, p. 741). Nevertheless, those, who have human capital specific to the MNE's subsidiary, usually experience lower wages on the local labour market (ibid) and have worse chance to find a decent job subsequently after the exit of MNE's subsidiary (Kauhanen and Napari, 2012). The latter scenario refers predominantly to the routine (originally blue-collar, but recently also white-collar) workers. Thus, MNE's routine subsidiary employees bear a substantial part of the employer's business risk too. Integration of local subsidiary activities with the rest of MNE, which can provide employees with desirable skills, is more frequent in high-tech industries compared to the low-tech industries, as Jarillo and Martínez (1990, p. 505) show.

Therefore, stakeholders, defined as those, who contribute to the wealth of corporation, and are influenced by its decisions and risks (Post, Preston and Sauter-Sachs 2002, p. 19), rightfully expect a reward for such contribution. There is a close, however, complex, relationship between such observable reward to shareholders and reward to other stakeholders. Frequently, if a company reports higher profits, then it also provides higher remunerations to employees (Blanchflower, Oswald and Sanfey, 1996) and pays higher taxes.

The transfer pricing influences the economic situation of MNE member, which spills over to suppliers (via pricing), to employees (via wages) and to government (via taxes). For example, GDP factor shares did not significantly change in the last 60 years (Atkinson, 2009; Feldstein, 2008), although the mainstream of workforce became significantly more financially distressed than the top $1 \%$ of the labour force (Atkinson, 2009; Haskel et al., 2012).

The cost-based transfer pricing increasingly dominates the market-based and negotiated pricing (Borkowski, 1996; Abu-Serdaneh et al., 2008; Terzioglu and Inglis, 2011; Jingna et al., 2011; Stephen, 2013) due to its managerial ease of use and ability to control the profits assigned to MNE's members, except for the financial institutions, where the market benchmarks are readily at close hand (Oyelere and Turner, 2000). That, 
together with the duality of transfer pricing: one set of books for tax purposes, the other for managerial ones (Hyde and Choe, 2005; Nielsen and Raimondos-Moller, 2012), enables the MNEs to tightly control profits of particular subsidiaries and impropriate the extraordinary profits. Indeed, the "transaction-specific investment and quality requirements", which are contemporary reality, "increase the likelihood that headquarters will centrally administer the pricing of transactions between divisions" (Shelanski, 2004).

Finally, the nature of the claims to assets of a limited liability company results in the uneven distribution of risk between shareholders and other stakeholders. Shareholders' claims to assets portray the buyer's position in call option, whereas the corporate liabilities constitute seller's position in put option, both on company assets (Black and Scholes, 1973; Vernimmen et al. 2014, pp. 721-729). Shareholders can decide about exercising those options, as their decisions can put company into bankruptcy risk.

Therefore, the stakeholders except for shareholders suffer from downside risks and do not enjoy the upside ones. MNE headquarters as the subsidiaries' shareholders increase their returns via ownership of the subsidiaries' debt (cp. Gravelle, 2010; Baker, 1973; Hurdle, 1974), and ultimately shift risks on the other stakeholders.

As a result of the above

1) Risk analysis during transfer pricing should include all stakeholders.

2) The downside risk measures should be used for evaluation of the stakeholders' risks. Credit institutions go that way (Bessis and O'Kelly, 2015), which supports our conclusion.

\section{Routine and Strategy Unit Risks}

MNE usually situates the valuable intangible assets at the top level of the corporate structure or separates them from production and distribution. The knowledge flows go from host country to MNE headquarters, wherever possible (Singh, 2007), equalizing the flow, which has formerly been considered unidirectional (for relevant citations see Driffield, Love and Yang, 2016). That could be response to the threats to the value of intangible assets (misuse, misappropriation, owner default). Besides that, the value of intangible assets at the parent level has significantly increased in recent decades (Dischinger and Riedel, 2011). Such asset allocation also provides excellent opportunity for profit shifting, and MNEs frequently exploit that chance (Grubert, 2003). Strategic knowledge is usually located at the parent and eventually transferred to subsidiary for a consideration (for literature review see Fang et al., 2007). Therefore, parent frequently embodies a strategy unit, and subsidiary impersonates a routine unit.

However, such an allocation evidently contradicts view of such assets and functions as the sources of risk. MNE's foremost interest is maximization of its headquarters equity value - via the value of both its core business and subsidiaries. Simultaneously, the headquarters has to be the most protected and stable component of MNE. Such a corporate design fits the findings of Bradley et al. (2011), who show that "the subsidiary organizations have low mortality rates when compared to independent organizations, but that their mortality 
rates increase more rapidly during a severe economic downturn" and that "surviving organizations founded independent of a parent organization have lower long-term failure rates than their protected subsidiary counterparts". Simply: if necessary, subsidiaries are sacrificed in order to keep the headquarters alive.

Therefore, ownership of valuable intangible assets (strategic knowledge) embodies strategy unit's power over the other MNE constituents (Mudambi and Navarra, 2004). The ownership of both marketing and technological intangible assets also increases the survivability of the owner (Delios and Beamish, 2001) and enables to standardize, or rather globalize, the MNE strategy (Begley and Boyd, 2003). The firms, which perform only routine functions, do not have significant $R \& D$ assets, do not spend enough on marketing and are not able to sell abroad, generally experience higher exit hazard rates (Esteve-Pérez and Mañez-Castillejo, 2008). Furthermore, the exit rates are higher, if exit costs are low (ibid). They also increase the fiscal risks and fiscal competition, as the heterogeneity within large MNEs enables and supports the profit shifting. Krautheim and Schmidt-Eiselhorn (2011) show that detrimental effect theoretically, and Griffith, Miller and O'Connel (2014) provide supportive evidence.

Naturally, a question emerges: if the routine units are riskier in the long term compared to strategy units, are they also riskier compared to independent peers?

\section{Exit Risk of Multinational Subsidiaries and Homegrown Companies}

Numerous papers provide evidence of the MNEs' subsidiaries exit risk. Technologically or otherwise superior (size, power) foreign subsidiaries fare better (Andersson, Forsgren and Pedersen, 2001; Agarwal and Audretsch, 2001). However, the MNEs' units without such superiority face equal or higher risk of downsizing, relocation, or closure compared to their homegrown peers in many countries (Wagner and Gelübcke, 2012; Andrews et al., 2012; Ferragina, Pittiglio, and Reganati, 2014). International element in corporate structure adds to downside risk after controlling for size, organizational slack, and investments (Reuer and Leiblein, 2000). Although foreign subsidiaries experienced high survivability several decades ago, the foreign ownership has ceased to decrease hazard rates recently (Kronborg and Thomsen, 2009; Mata and Portugal, 2002; Bellak, 2004) and started to increase them (Görg and Strobl, 2003), even after controlling the data for other differences (Mudambi and Zahara, 2007; Wagner, Gelübcke and Philipp, 2013; Mata and Freitas, 2012; Bandick, 2010; Bernard and Jensen, 2007). On the other hand, domestic non-exporting companies seem to close down more frequently, compared to MNE members in the host country (Bandick, 2010), which is probably caused by the MNEs ability to offshore the profitable activities (Coucke and Sleuwaegen, 2007). It is probably the international experience of $\mathrm{MNE}$, which creates the mobility advantage of MNE members over domestic independent peers. The downsizing, exit and relocation risks emerge due to "parents restructuring their portfolios or winding down their options", rather than due to foreignness liability, although the cultural gap could be the culprit too (Hennart, Roehl and Zeng, 2002). Indeed, exits of foreign subsidiaries frequently proceed via downsizing and relocation (Belderbos and Zou, 2006), which also makes them riskier 
employers (Andrews et al., 2012). Moreover, exit hazard rate of MNE subsidiaries increases relatively to the peer indigenous firms with the increasing maturity of the host country market (see the above papers).

As already mentioned, if a company reports higher profits, then it also provides higher remunerations to employees (Blanchflower, Oswald and Sanfey, 1996). That sometimes happens also at cross-border level. However, the elasticity of affiliate wages to MNEs' parents profits has been observed at 0.03 (Budd, Konings and Slaughter, 2005). This miserable success sharing can explain more than $20 \%$ of affiliate wages variation (ibid). The impropriation of success at the parent level is evident. Wage hysteresis could be the reason for such hesitant success sharing. However, the MNE's risk is probably shared with stakeholders (other than shareholders) under higher elasticity. Moreover, the internationally diversified joint ventures experience larger downside risks than other organizations during the times of economic downturn (Reuer, and Leiblein, 2000).

The probable reasons for the higher survival rate of strategy unit are that the risks malignant to the strategy unit endanger also the routine unit and, on the contrary, the impact of routine unit risks on the strategy unit is limited. That holds especially in the case of strategy parent and routine subsidiary. The strategy unit can more easily replace the performer of routine functions, whilst the loss of strategy partner poses existential risk to the routine unit. Productive routine units probably suffer from that trouble more than non-productive (distribution), as the access to customer is precious.

\section{The Upside and Downside Risk}

OECD (2010) guidelines do not specify a risk measure applicable to the functional analysis. EU Joint transfer pricing forum discussion paper (2014) still provides only vague description of risk analysis (p. 11) applicable in transfer pricing in the EU, and even states that "Where a Member State requires a taxpayer to submit information about transfer pricing with its tax return, that information should be no more than a short questionnaire or an appropriate risk assessment form." OECD (2013) Draft Handbook on Transfer Pricing Risk Assessment fares no better. In fact, it follows an appeasement policy, as there are no clear indicators of high risk of profit-shifting outlined there, but it cites any possible indicator of low taxavoidance risk. Besides the vintage intervals of profitability ratios, there is no rigorous approach of risk assessment outlined in there.

As documented above, stakeholders other than shareholders experience rather downside (pure) risks, especially in the case of routine units. The pure (downside) risk is a risk of worse than expected (average) results. With current transfer pricing regulations, the expected (stipulated) rate of return of the routine subsidiaries frequently approaches the risk-free rate, thus its pure risk is that the profits will not reach that threshold. Such a risk emerges, if the parent is either not able or not willing to compensate the below-expected profits (losses) of the subsidiary, which is mostly the case of its multi-year significant losses (exit risk). That leaves the large upside risks to the shareholders of the routine unit and the large downside risks to its other stakeholders. Thus, the pure (downside) risk measures 
should be the generally stipulated choice for the risk assessment in the case of transfer pricing ${ }^{1}$, because

1) transfer price determines the payout function to all stakeholders;

2) shareholders can mitigate the impact of routine unit's downside risk both by profit distribution from the subsidiary towards them and by transfer pricing;

3) pure risk is superior to the (total) risk in terms of required return explanation, as documented below;

4) pure-risk based transfer pricing would induce fair creation of value within MNE members that provides reserves against such risks.

Required return (or income or rent) is usually positively related to pure risk. Pure risk shows higher explanatory power of the financial markets returns than the total risk (cp. Hogan and Warren, 1974; Bawa and Lindenberg, 1977; Harlow and Rao, 1989). Stock market returns are related to the downside more than to the upside or total risk, especially in the case of significant coskewness between the market portfolio and the individual stock (Ang, Chen and Xing, 2006). The recently examined downside risk measures include the semi-variance, the standard semi-deviation (Mao, 1970), and the downside beta (Bawa and Lindenberg, 1977; Ang, Chen and Xing, 2006). Although Estrada (2007) defines the downside beta differently from the previous authors, he still finds it superior to the traditional beta used by Sharpe (1964) in CAPM model, even after extension of CAPM for size and value risk measures (Banz, 1981 and the subsequent ones). Therefore, the pure risk measures are also superior in representing the risk-reward relationship, compared to the traditional ones (like variance and standard deviation).

Extensibility of our conclusions to multi-company MNEs requires risk measures applicable in portfolio optimization models as MNE's tax optimization is a portfolio optimization problem (Brada and Buus, 2009).

Downside betas as well as their constituents like semi-covariance and semi-variance (see e.g. Ang, Chen and Xing, 2006 or Estrada, 2007) are not translation invariant (cp. Cherny, 2010, pp. 571-572). Moreover, they do not translate the higher returns into lower risk, for they are mean-lower partial moments. Therefore, we have to look for other pure risk measures or modify the above ones.

The market return (average) is the preferred choice for the threshold in downside risk measures (Harlow and Rao, 1989; Bertsimas, Lauprette and Samarov, 2004; Ang, Chen and Xing, 2006), since it disconnects applicability of such measure from the subjectivity of researcher's opinion.

Replacing the first central moments (averages) in downside covariance and variance threshold with constant allows translating the return increase into risk decrease, although it still does not render translation invariant lower partial moments. Furthermore, it shows the risk that the followed variable does not reach the required level (e.g. company is at exit risk if its cost of capital exceed its profits).

Risk assessment is obligatory part of the transfer pricing analysis (EU Joint Transfer Pricing Forum, 2014; OECD, 2013), which determines both the transfer price and the profit (one of them directly, the other indirectly) assigned to the contracting related parties. 
Coherent risk measures can provide the same service in the translation invariant (proportional) way. Artzner et al. (1999) describe the properties of expected shortfall and tail conditional expectation at level $\alpha$ (hereinafter $E S_{\alpha}$, or $T C E_{\alpha}$ ), which both represent mean of the tail of the probability distribution. In other words, $T C E$ and expected shortfall (some authors write only "shortfall") represent the sum of all outcomes ( $E S_{\alpha}$ uses values at risk) below an user-determined percentile $\alpha$, divided by probability of that percentile. That shows how large losses one would suffer on the average in worst $\alpha$ of the results. Acerbi and Tasche (2002) show that $E S_{\alpha}$ and $T C E_{\alpha}$ are equal if the probability distribution of the examined variable is continuous. Let us note that $E S_{100 \%}$ and $T C E_{100 \%}$ are equal to mean (arithmetic average).

Bertsimas, Lauprette and Samarov (2004) note that "mean-shortfall optimization problem, unlike mean-VaR, can be solved efficiently as a convex optimization problem, while the sample mean-shortfall portfolio optimization problem can be solved very efficiently as a linear optimization problem".

Bali, Demirtas and Levy (2009) compare the ability of VaR, expected shortfall, and variance to explain the relationship between risk and return at the US stock markets. They find VaR by far superior to the traditional risk measures, but also by narrow margin better than the conditional risk measures $\left(E S_{\alpha}\right.$, or $\left.T C E_{\alpha}\right)$. That could be the result of market participants' concentration on VaR, although entire left tail risk matters. Furthermore, Gemmill and Keswani (2011) conclude that risk premiums in bonds' required returns (i.e. credit spreads) "are large because they incorporate a large risk premium related to investors' fears of extreme losses", as the short-term volatility is rather noise. Most of the stakeholders of any company with limited liability (except for shareholders) are de facto creditors. Therefore, the downside risks, which materialize only in the long term and are lethal to the company, are relevant to them. Transfer pricing regulation design should concentrate on downside risk measures then.

\section{Model}

The evidence we have found in literature, or the basic economic axioms:

1) separation of transfer pricing decisions from other corporate decisions;

2) the nature of current (OECD, EU TPD) guidelines;

3) the mobility advantage (higher exit risk) of MNE members over the comparable domestic companies;

4) the necessity of a company to generate at least zero (better positive) rents for survival in the long term

allow us to set up a model with the subsequent assumptions:

i) Routine units are generally viewed as low-risk ones, which leaves them with lower risk compensation in the profit compared to independent peers.

ii) Transfer pricing guidelines allow the MNE to set the transfer price so that routine unit can participate $0 \%$ to $100 \%$ on profits above risk free return.

iii) The earning ability of MNE subsidiary is equal or above the earning ability of independent peers. Up to $100 \%$ is reported at the subsidiary.

iv) MNE has a mobility advantage (possibility of relocation) over the independent peers. 
Under those assumptions:

a. If the cost of capital paid by a company (be it MNE subsidiary or domestic independent peer) to capital providers is below the cost of capital required, then the company exits

o via bankruptcy, if the interest paid to capital providers (creditors, share-holders) does not reach interest levied on debt,

o via relocation, if the interest paid to capital owners is between interest levied on debt and the profit achievable after relocation.

b. If the cost of capital paid by a company to capital providers is above the cost of capital required, then the company

o reports all the profits at the host country, if it cannot use transfer pricing (is not MNE member),

o reports profits ranging from risk-free return to expected profits of independent peers.

Figure 1 | Comparison of the Profit Reported by the Routine Member of MNE at the Host Country and by the Independent Peer

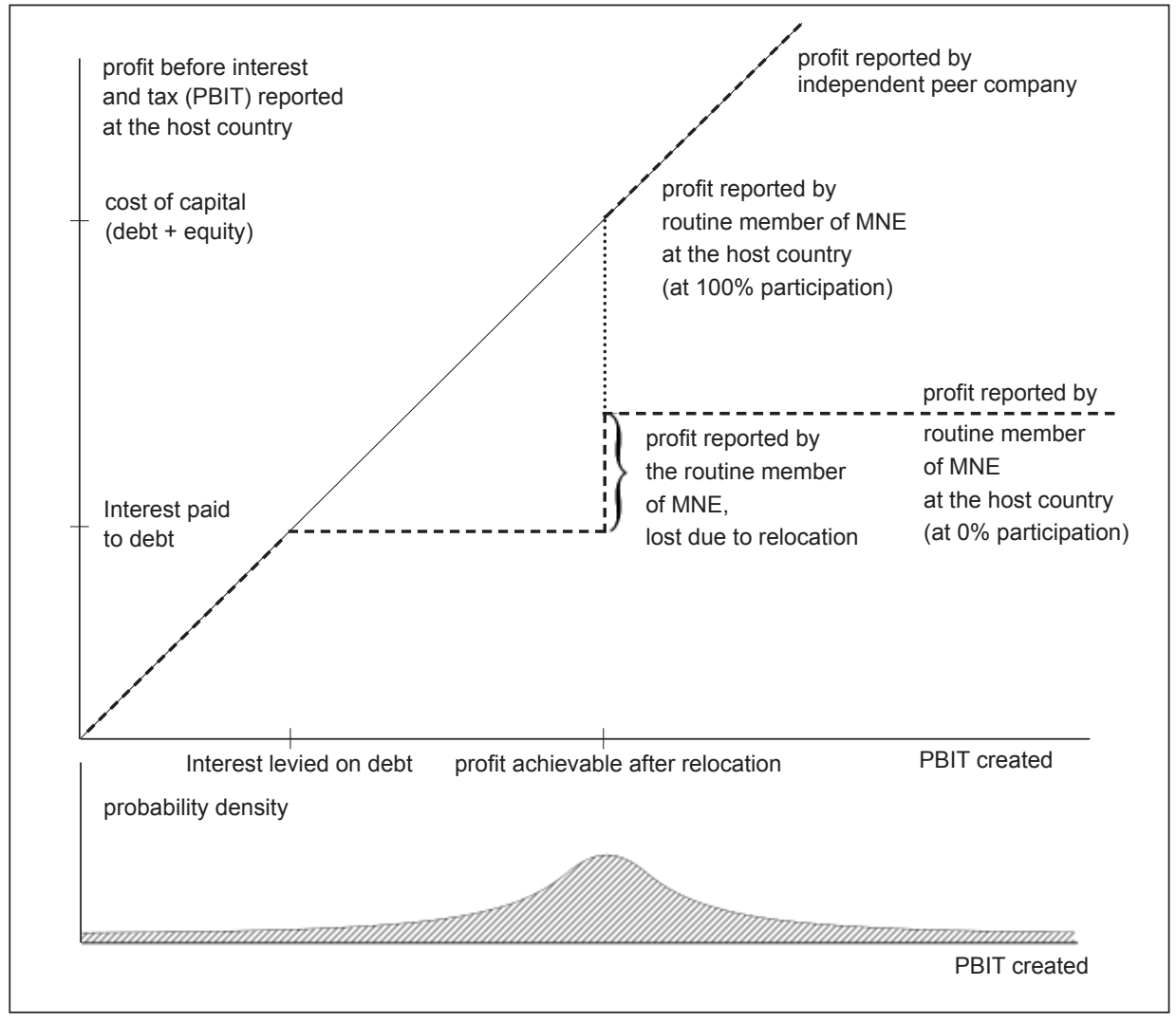

Source: Author's own scheme 
At the independent peer, the profit before interest and tax (PBIT) reported $=$ PBIT created. At the routine member of MNE, the PBIT reported at the host country:

- equals the profit created until the full ability of the MNE routine member to repay interest on debt (not to default), because MNE choses bankruptcy solution as the most economically advantageous to the shareholders;

- is at the level of interest on debt, if

interest on debt required $<$ PBIT created $<$ PBIT achievable after relocation;

because MNE in line with economic rationale choses to repay debt + interest and relocate into another country;

- is at the level of interest on debt + near-risk free return to the equity (or full reporting of achieved profit), as the OECD transfer pricing guidelines (EU TPD) allows routine unit to be viewed as nearly-risk free and set the transfer price (allocate profits) accordingly, but do not exclude the possibility profits of routine member of MNE at the level achieved by independent peers.

\section{Simulation}

Let us show how the choice of examined variable and risk measure influences results of risk assessment. The simulation replicates regularities shown in Figure 1. Simulation parameters are:

1) PBIT of independent peer $\sim \mathrm{N}[100 ; 30]$; PBIT of routine member of MNE simulated according to Figure 1;

2) required interest on debt $=30$;

3) profit achievable after relocation $=80$;

4) risk-free return on equity $=30$, required risk premium on equity $=40$;

5) routine member of MNE has participation rate on achieved risk premium between $0 \%$ and $100 \%$ (if achieved premium $>0$ );

6) corporate income tax rate $=0 \%$ (for the sake of simplicity).

Number of simulated cases $=10,000(1$ step $=0.01 \%$ in CDF domain $)$.

The three cases are:

- $\quad$ risk is measured via PBIT, or EAT standard deviation

- $\quad$ risk is measured via PBIT, or EAT expected shortfall $E S_{100}\left(T C E_{100}\right)$.

The Table 1 displays the simulation results. The downside risk measures show that the inability of routine member of MNE to enjoy the upside potential similarly to its independent peer results into increased risk. Standard deviation shows the opposite, although the dent in PBIT function caused by relocation possibility increases the risk even in this case. 


\begin{tabular}{|l|c|c|c|c|c|c|}
\hline \multirow{2}{*}{ Statistics } & \multicolumn{2}{|c|}{ TCE $^{*}{ }_{100 \%}$} & \multicolumn{2}{c|}{ Standard deviation } & \multicolumn{2}{c|}{ Semideviation } \\
\hline & PBIT & EAT & PBIT & EAT & PBIT & EAT \\
\cline { 2 - 7 } & \multicolumn{7}{|c|}{ Independent peer } \\
\cline { 2 - 7 } & 0.02 & 0.02 & 30.06 & 30.06 & 21.19 & 21.19 \\
\hline $\begin{array}{l}\text { Participation in } \\
\text { achieved risk premium }\end{array}$ & \multicolumn{7}{|c|}{ MNE member } \\
\hline $\mathbf{0 \%}$ & -47.67 & -47.67 & 13.26 & 13.26 & 49.48 & 49.48 \\
\hline $\mathbf{2 0 \%}$ & -39.77 & -39.77 & 18.24 & 18.24 & 43.75 & 43.75 \\
\hline $\mathbf{4 0 \%}$ & -31.87 & -31.87 & 23.67 & 23.67 & 39.68 & 39.68 \\
\hline $\mathbf{6 0} \%$ & -23.97 & -23.97 & 29.31 & 29.31 & 37.44 & 37.44 \\
\hline $\mathbf{8 0} \%$ & -16.07 & -16.07 & 35.06 & 35.06 & 36.35 & 36.35 \\
\hline $\mathbf{1 0 0} \%$ & -8.17 & -8.17 & 40.87 & 40.87 & 35.82 & 35.82 \\
\hline
\end{tabular}

Note: $\mathrm{PBIT}=$ profit before interest and tax, $\mathrm{EAT}=$ earnings after tax, i.e. $\mathrm{PBIT}-$ interest on debt tax; tax rate $=0 \%$; PBIT of independent peer $\sim$ N[100;30]; required interest on debt $=30$; PBIT value $T C E^{*}{ }_{100 \%}=T C E_{100 \%}-\mu_{\text {independent peer }}$, i.e. it shows risk relative to average profit achievable by independent peer ( $\left.\mu_{\text {independent peer }}\right)$, which is 100 in the case of PBIT and 70 in the case of EAT

Semideviation = below target semideviation (cp. Nawrocki, 1999). The target (threshold) $=$ average profit achievable by independent peer, which is 100 in the case of PBIT and 70 in the case of EAT.

Source: Own calculation

\section{Conclusions}

This paper analyses and compares the risks of routine and strategy unit in a multinational enterprise (MNE), resp. risks of MNE subsidiary and unrelated party (independent peer). Review of available evidence, which also allows us to set up realistic assumptions for the subsequent graphical and mathematical analysis, shows that routine units are riskier than strategy units in terms of long-term downside risk, and equally or more risky compared to the independent peers. The available evidence suggests that the future design of transfer pricing regulations should concentrate on the stakeholders' viewpoint, and longterm (extreme downside) risks. All stakeholders are the risk bearers. However, the risk distribution among them can be uneven and only the shareholders can enjoy the upside risks while the other stakeholders suffer mainly from the downside risks.

Mobility advantage of routine unit (or MNE member in general) compared to the standalone peer decreases stakeholders' observable pure risk. However, only shareholders can benefit from MNE subsidiary's mobility advantage. Thus, the other stakeholders (creditors, govern-ment, employees, public) are negatively influenced by footlooseness of MNE subsidiaries. The same holds in the case of routine unit's transfer prices, which should ensure "stable and low" profits according to OECD transfer pricing guidelines. However, such a transfer pricing stabilizes profits only in the short term and does not decrease downside risks of stakeholders other than shareholders. 
The results of this paper provide guide for reassessment of the principles of risk analysis regulation in transfer pricing. Moreover, this paper constitutes basis for further research, especially for development of formal mathematical model, which would describe the relative risks of strategy and routine units and their peers, and the rationale behind allocation of intangible assets and strategy functions within MNE.

\section{References}

Abu-Serdaneh, J. A., Al-Okdeh, S. K., Gauher, K. A. (2008). Transfer Pricing in Jordanian Manufacturing Companies. Jordan Journal wof Business Administration, 11(2), 313-330.

Acerbi, C., Tasche, D. (2002). On the Coherence of Expected Shortfall. Journal of Banking \& Finance, 26(7), 1487-1503, https://doi.org/10.1016/s0378-4266(02)00283-2

Agarwal, R., Audretsch, D. B. (2001). Does Entry Size Matter? The Impact of the Life Cycle and Technology on Firm Survival. The Journal of Industrial Economics, 49(1), 21-43, https://doi. org/10.1111/1467-6451.00136

Andersson, U., Forsgren, M., Pedersen, T. (2001). Subsidiary Performance in Multinational Corporations: the Importance of Technology Embeddedness. International Business Review, 10(1), 3-23, https://doi.org/10.1016/s0969-5931(00)00042-1

Andrews, M., Bellmann, L., Schank, T., Upward, R. (2012). Foreign-Owned Plants and Job Security. Review of World Economics, 148(1), 89-117, https://doi.org/10.1007/s10290-011-0110-1

Ang, A., Chen, J., Xing, Y. (2006). Downside Risk. Review of Financial Studies, 19(4), 1191-1239, https://doi.org/10.1093/rfs/hhj035

Artzner, P., Delbaen, F., Eber, J. M., Heath, D. (1999). Coherent Measures of Risk. Mathematical finance, 9(3), 203-228.

Atkinson, A. B. (2009). Factor Shares: The Principal Problem of Political Economy? Oxford Review of Economic Policy, 25(1), 3-16, https://doi.org/10.1093/oxrep/grp007

Baker, S. H. (1973). Risk, Leverage and Profitability: an Industry Analysis. The Review of Economics and Statistics, 55(4), 503-507, https://doi.org/10.2307/1925675

Bali, T. G., Demirtas, K. O., Levy, H. (2009). Is there an Intertemporal Relation between Downside Risk and Expected Returns? Journal of Financial and Quantitative Analysis, 44(04), 883-909, https://doi.org/10.1017/s0022109009990159

Bandick, R. (2010). Multinationals and Plant Survival. Review of World Economics, 146(4), 609-634, https://doi.org/10.1007/s10290-010-0068-4

Banz, R. W. (1981). The Relationship between Return and Market Value of Common Stocks. Journal of Financial Economics, 9(1), 3-18, https://doi.org/10.1016/0304-405x(81)90018-0

Bawa, V. S., Lindenberg, E. B. (1977). Capital Market Equilibrium in a Mean-Lower Partial Moment Framework. Journal of Financial Economics, 5(2), 189-200, https://doi. org/10.1016/0304-405x(77)90017-4

Beer, S., Loeprick, J. (2015). Profit Shifting: Drivers of Transfer (Mis) Pricing and the Potential of Countermeasures. International Tax and Public Finance, 22(3), 426-451, https://doi. org/10.1007/s10797-014-9323-2

Bellak, C. (2004). How Domestic and Foreign Firms Differ and Why Does It Matter? Journal of Economic Surveys, 18(4), 483-514, https://doi.org/10.1111/j.0950-0804.2004.00228.x

Belderbos, R., Zou, J. (2006). Foreign Investment, Divestment and Relocation by Japanese Electronics Firms in East Asia*. Asian Economic Journal, 20(1), 1-27, https://doi. org/10.1111/j.1467-8381.2006.00222.x 
Begley, T. M., Boyd, D. P. (2012). The Need for a Corporate Global Mind-Set. MIT Sloan Management Review, 44(2).

Bernard, A. B., Jensen, J. B. (2007). Firm Structure, Multinationals, and Manufacturing Plant Deaths. The Review of Economics and Statistics, 89(2), 193-204, https://doi.org/10.1162/ rest.89.2.193

Bertsimas, D., Lauprete, G. J., Samarov, A. (2004). Shortfall as a Risk Measure: Properties, Optimization and Applications. Journal of Economic Dynamics and Control, 28(7), 1353-1381, https://doi.org/10.1016/s0165-1889(03)00109-x

Bessis, J., O’Kelly, B. (2015). Risk Management in Banking. John Wiley \& Sons. ISBN 978-1-118-66021-8.

Black, F., Scholes, M. (1973). The Pricing of Options and Corporate Liabilities. The Journal of Political Economy, 81(3), 637-654, https://doi.org/10.1086/260062

Blanchflower, D., Oswald A., Sanfey, P. (1996). Wages, Profits, and Rent-Sharing. Quarterly Journal of Economics, 111(1), 227-251, https://doi.org/10.2307/2946663

Bowles, S., Gintis, H. (1975). The Problem with Human Capital Theory - a Marxian Critique. The American Economic Review, 65(2), 74-82.

Borkowski, S. C. (1996). An Analysis (Meta-and Otherwise) of Multinational Transfer Pricing Research. The International Journal of Accounting, 31(1), 39-53, https://doi.org/10.1016/ s0020-7063(96)90012-6

Brada, J., Buus, T. (2009). Detection of Possible Tax-Evasive Transfer Pricing in Multinational Enterprises. European Financial and Accounting Journal, 4(2), 65-78, https://doi. org/10.18267/j.efaj.67

Bradley, S. W., Aldrich, H., Shepherd, D. A., Wiklund, J. (2011). Resources, Environmental Change, and Survival: Asymmetric Paths of Young Independent and Subsidiary Organizations. Strategic Management Journal, 32(5), 486-509, https://doi.org/10.1002/smj.887

Budd, J. W., Konings, J., Slaughter, M. J. (2005). Wages and International Rent Sharing in Multinational Firms. Review of Economics and Statistics, 87(1), 73-84, https://doi.org/10.1162/0034653053327586

Cherny, A. S. (2010). Risk-Reward Optimization with Discrete-Time Coherent Risk. Mathematical Finance, 20(4), 571-595, https://doi.org/10.1111/j.1467-9965.2010.00412.x

Coucke, K., Sleuwaegen, L. (2007). Offshoring as a Survival Strategy in Globalizing Industries: New Evidence from Belgian Manufacturing. Available at: https:// www.lirias.kuleuven.be/ bitstream/123456789/265119/1/2010-03-24

Delios, A., Beamish, P. W. (2001). Survival and Profitability: The Roles of Experience and Intangible Assets in Foreign Subsidiary Performance. Academy of Management Journal, 44(5), 1028-1038, https://doi.org/10.2307/3069446

Dischinger, M., Riedel, N. (2011). Corporate Taxes and the Location of Intangible Assets within Multinational Firms. Journal of Public Economics, 95(7-8), 691-707, https://doi.org/10.1016/j.jpubeco.2010.12.002

Driffield, N., Love, J. H., \& Yang, Y. (2016). Reverse International Knowledge Transfer in the MNE: (Where) Does Affiliate Performance Boost Parent Performance? Research Policy, 45(2), 491-506, https://doi.org/10.1016/j.respol.2015.11.004

Dugová, A. (2013). Changes in the Value Added Tax as the Tool against the Global Crisis. European Financial and Accounting Journal, 8(3), 74-93, https://doi.org/10.18267/j.efaj.108 
Eden, L. (2012). Transfer Price Manipulation. Draining Development? in Reuer, P., ed., Controlling Flows of Illicit Funds from Developing Countries. Washington: World Bank, 205-234.

Esteve-Pérez, S., Mañez-Castillejo, J. A. (2008). The Resource-Based Theory of the Firm and Firm Survival. Small Business Economics, 30(3), 231-249, https://doi.org/10.1007/ s11187-006-9011-4

Estrada, J. (2007). Mean-Semivariance Behavior: Downside Risk and Capital Asset Pricing. International Review of Economics \& Finance, 16(2), 169-185, https://doi.org/10.1016/j. iref.2005.03.003

EU Joint Transfer Pricing Forum (2014). Discussion Paper on Improving the Functioning of the EU TPD. [online, cit. 25th March 2015]. Available at: http:// www.ec.europa.eu/taxation_ customs/resources/documents/taxation/company_tax/transfer_pricing/forum/jtpf/2014/ jtpf_010_2014_en.pdf

Fang, Y., Wade, M., Delios, A., Beamish, P. W. (2007). International Diversification, Subsidiary Performance, and the Mobility of Knowledge Resources. Strategic Management Journal, 28(10), 1053-1064, https://doi.org/10.1002/smj.619

Feldstein, M. (2008). Did Wages Reflect Growth in Productivity? Journal of Policy Modeling, 30(4), 591-594, https://doi.org/10.1016/j.jpolmod.2008.04.003

Ferragina, A. M., Pittiglio, R., Reganati, F. (2014). Does Multinational Ownership Affect Firm Survival in Italy? Journal of Business Economics and Management, 15(2), 335-355, https://doi.org/10.3846/16111699.2012.707622

Friedman, M. (1962). Capitalism and Freedom. Chicago: University of Chicago Press.

Gemmill, G., Keswani, A. (2011). Downside Risk and the Size of Credit Spreads. Journal of Banking \& Finance, 35(8), 2021-2036, https://doi.org/10.1016/j.jbankfin.2011.01.019

Görg, H., Strobl, E. (2003). Multinational Companies, Technology Spillovers and Plant Survival*. The Scandinavian journal of economics, 105(4), 581-595, https://doi. org/10.1111/j.0347-0520.2003.t01-1-00003.x

Gravelle, J. G. (2010). Tax Havens: International Tax Avoidance and Evasion. Congressional Research Service, 40623.

Griffith, R., Miller, H., O'Connell, M. (2014). Ownership of Intellectual Property and Corporate Taxation. Journal of Public Economics, 112, 12-23, https://doi.org/10.1016/j. jpubeco.2014.01.009

Grosfeld, I., Nivet, J. F. (1999). Insider Power and Wage Setting in Transition: Evidence from a Panel of Large Polish Firms, 1988-1994. European Economic Review, 43(4), 1137-1147, https://doi.org/10.1016/s0014-2921(98)00121-4

Grubert, H. (2003). Intangible Income, Intercompany Transactions, Income Shifting, and the Choice of Location. National Tax Journal, 56(1), 221-242, https://doi.org/10.17310/ntj.2003.1s.05

Harlow, W. V., Rao, R. K. (1989). Asset Pricing in a Generalized Mean-lower Partial Moment Framework: Theory and Evidence. Journal of Financial and Quantitative Analysis, 24(3), 285-311, https://doi.org/10.2307/2330813

Haskel, J., Lawrence, R. Z., Leamer, E. E., Slaughter, M. J. (2012). Globalization and US Wages: Modifying Classic Theory to Explain Recent Facts. The Journal of Economic Perspectives, 26(2), 119-139, https://doi.org/10.1257/jep.26.2.119

Hennart, J. F., Roehl, T., Zeng, M. (2002). Do Exits Proxy a Liability of Foreignness? The Case of Japanese Exits from the US. Journal of International Management, 8(3), 241-264, https://doi.org/10.1016/s1075-4253(02)00065-0

Hettich, W. (2005). Tax Price, in Cordes, J. J., Ebel, R. D., Gravelle, J., eds., The Encyclopedia of Taxation \& Tax Policy. The Urban Insitute. 
Hogan, W. W., Warren, J. M. (1974). Toward the Development of an Equilibrium Capital-Market Model Based on Semivariance. Journal of Financial and Quantitative Analysis, 9(1), 1-11, https://doi.org/10.2307/2329964

Hurdle, G. J. (1974). Leverage, Risk, Market Structure and Profitability. The Review of Economics and Statistics, 56(4), 478-485, https://doi.org/10.2307/1924463

Hyde, C. E., Choe, C. (2005). Keeping Two Sets of Books: The Relationship between Tax and Incentive Transfer Prices. Journal of Economics \& Management Strategy, 14(1), 165-186, https://doi.org/10.1111/j.1430-9134.2005.00038.x

Jarillo, J., Martínez, J. I. (1990). Different Roles for Subsidiaries: The Case of Multinational Corporations in Spain. Strategic Management Journal, 11(7), 501-512, https://doi. org/10.1002/smj.4250110702

Jingna, L., Seng, D., Wynn-Williams, K. (2011). Performance Evaluation and International Transfer Pricing in Foreign Subsidiaries of Japanese Companies. Asia-Pacific Management Accounting Journal, 6(1), 1-24.

Kauhanen, A., Napari, S. (2012). Career and Wage Dynamics: Evidence from Linked Employeremployee Data. Journal of Labor Research, 36, 35-76, https://doi.org/10.1108/ s0147-9121(2012)0000036006

Krautheim, S., Schmidt-Eisenlohr, T. (2011). Heterogeneous Firms,'Profit Shifting'FDI and International Tax Competition. Journal of Public Economics, 95(1), 122-133, https://doi.org/10.1016/j.jpubeco.2010.10.008

Kronborg, D., Thomsen, S. (2009). Foreign Ownership and Long-Term Survival. Strategic Management Journal, 30(2), 207-219, https://doi.org/10.1002/smj.732

Maffini, G., Mokkas, S. (2011). Profit Shifting and Measured Productivity of Multinational Firms*. Oxford Bulletin of Economics and Statistics, 73(1), 1-20, https://doi. org/10.1111/j.1468-0084.2010.00610.x

Mao, J. C. T. (1970). Survey of Capital Budgeting: Theory and Practice. Journal of Finance, 25(2), 349-360, https://doi.org/10.1111/j.1540-6261.1970.tb00513.x

Mata, J., Freitas, E. (2012). Foreignness and Exit over the Life Cycle of Firms. Journal of International Business Studies, 43(7), 615-630, https://doi.org/10.1057/jibs.2012.21

Mata, J., Portugal, P. (2002). The Survival of New Domestic and Foreign-Owned Firms. Strategic Management Journal, 23(4), 323-343, https://doi.org/10.1002/smj.217

Mudambi, R., Navarra, P. (2004). Is Knowledge Power? Knowledge Flows, Subsidiary Power and Rent-Seeking within MNCs. Journal of International Business Studies, 35(5), 385-406, https://doi.org/10.1057/palgrave.jibs.8400093

Mudambi, R., Zahra, S. A. (2007). The Survival of International New Ventures. Journal of International Business Studies, 38(2), 333-352, https://doi.org/10.1057/palgrave. jibs.8400264

Nawrocki, D. (1999). A Brief History of Downside Risk Measures. The Journal of Investing, 8(3), 9-25, https://doi.org/10.3905/joi.1999.319365

Nielsen, S. B., Raimondos-Møller, P. (2012). Multiple Roles of Transfer Prices: One vs. Two Books. In Fundamentals of International Transfer Pricing in Law and Economics (pp. 25-46).

Springer Berlin Heidelberg. https://doi.org/10.1007/978-3-642-25980-7_3

OECD (2010). OECD Transfer Pricing Guidelines for Multinational Enterprises and Tax Administrations 2010. OECD Publishing.

OECD (2013). Public Consultation: Draft Handbook on Transfer Pricing Risk Assessment. OECD Publishing. [online, cit. 25th March 2015]. Available at: www: http://www.oecd.org/tax/ transfer-pricing/Draft-Handbook-TP-Risk-Assessment-ENG.pdf 
Oyelere, P. B., Turner, J. D. (2000). A Survey of Transfer Pricing Practices in UK Banks and Building Societies. European Business Review, 12(2), 93-99, https://doi. org/10.1108/09555340010318673

Post, J. E., Preston, L. E., Sauter-Sachs, S. (2002). Redefining the Corporation: Stakeholder Management and Organizational Wealth. Stanford University Press. ISBN 9780804743105.

Rahman, M. Z., Scapens, R. W. (1986). Transfer Pricing by Multinationals: Some Evidence from Bangladesh. Journal of Business Finance \& Accounting, 13(3), 383-391, https://doi.org/10.1111/j.1468-5957.1986.tb00503.x

Reuer, J. J., Leiblein, M. J. (2000). Downside Risk Implications of Multinationality and International Joint Ventures. Academy of Management Journal, 43(2), 203-214, https://doi.org/10.2307/1556377

Saunders-Scott, M. J. (2015). Substitution across Methods of Profit Shifting. National Tax Journal, 68(4), 1099-1120, https://doi.org/10.17310/ntj.2015.4.09

Schultz, T. W. (1972). Human Capital: Policy Issues and Research Opportunities, in Economic Research: Retrospect and Prospect, Volume 6, Human Resources (1-84). NBER.

Sharpe, W. F. (1964). Capital Asset Prices: A Theory of Market Equilibrium under Conditions of Risk*. The Journal of Finance, 19(3), 425-442, https://doi.org/10.1111/j.1540-6261.1964. tb02865.x

Shelanski, H. A. (2004). Transaction-Level Determinants of Transfer-Pricing Policy: Evidence from the High-Technology Sector. Industrial and Corporate Change, 13(6), 953-966, https://doi.org/10.1093/icc/dth037

Sikka, P., Willmott, H. (2010). The Dark Side of Transfer Pricing: Its Role in Tax Avoidance and Wealth Retentiveness. Critical Perspectives on Accounting, 21(4), 342-356, https://doi. org/10.1016/j.cpa.2010.02.004

Singh, J. (2007). Asymmetry of Knowledge Spillovers between MNCs and Host Country Firms. Journal of International Business Studies, 38(5), 764-786.

Sofka, W., Preto, M. T., de Faria, P. (2014). MNC Subsidiary Closures: What is the Value of Employees' Human Capital in New Jobs? Journal of International Business Studies, 45(6), 723-750, https://doi.org/10.1057/jibs.2014.17

Stephen, M. (2013). Transfer Pricing: Goals and Methods among Unlisted Companies in Kenya. Interdisciplinary Journal of Research in Business, 2(12), 26-34.

Terzioglu, B., Inglis, R. (2011). Transfer Pricing in Australian Service Organisations. Asia-Pacific Management Accounting Journal, 6(2), 85-106.

Timmons, J. F. (2005). The Fiscal Contract: States, Taxes, and Public Services. World Politics, 57(4), 530-567, https://doi.org/10.1353/wp.2006.0015

Tucha, T., Brem, M. (2007). Documentation of Transfer Pricing: The Nature of Arm's Length Analysis, in Read, C., Gregoriou, G. N., eds., International Taxation Handbook: Policy, Practice, Standards and Regulations. Burlington: Elsevier, 147-169.

Vernimmen, P., Quiry, P., Dallocchio, M., Le Fur, Y., Salvi, A. (2014). Corporate Finance: Theory and Practice. John Wiley \& Sons. ISBN 9781118849330.

Wagner, J., Gelübcke, J. P. W. (2012). Foreign Ownership and Firm Survival: First Evidence for Enterprises in Germany. Economie Internationale, 132(4), 117-139, https://doi. org/10.1016/s2110-7017(13)60060-8

Wagner, J., Gelübcke, W., Philipp, J. (2013). Foreign Ownership and Firm Survival: First Evidence for Enterprises in Germany. Economie Internationale, (4), 117-139. 